\title{
The Samaritan Pentateuch and the Scribal Culture of Second Temple Judaism
}

Abstract: The Samaritan Pentateuch (SP), along with its Qumran forebears, has deservedly been regarded as a key source of information for understanding the scribal culture of early Judaism. Yet studies have tended to emphasize the relative uniformity of the characteristic pre-SP readings as evidence of a scribal approach distinct within Second Temple Judaism. This article argues that both the uniformity and the distinctiveness of these readings have been overstated: there is more internal diversity within pre-SP than is usually recognized, and similar or identical readings are also preserved in other manuscript traditions. Rather than representing a distinctive scribal approach or school, the readings of pre-SP are better taken as a particularly concentrated example of scribal attitudes and techniques that appear to have been widespread in early Judaism.

Keywords: Samaritan Pentateuch, Pre-Samaritan Texts, Second Temple Judaism, Scribes, Scribal Culture, Harmonization, Qumran Biblical Manuscripts, Hellenistic Culture, 4QpaleoExod ${ }^{\mathrm{m}}, 4 \mathrm{QNum}{ }^{\mathrm{b}}$

Scholars seeking to understand the ways texts were composed and transmitted in ancient Judaism often struggle with how to connect textual evidence with historical and cultural realities. ${ }^{1}$ In earlier stages of scholarship, such issues were not usually regarded as especially important. Analysis of biblical manuscripts and versions focused primarily on recovery of the "original text"; in this sense, materials introduced by scribes in the course of transmission were treated as significant only insofar as, once identified, these materials could be bracketed out, and something closer to the Urtext could be reconstructed. ${ }^{2}$ More recently, much more attention has been paid to such scribal interventions as cultural products in their own right; as windows not just on the development of the text but on the attitudes and ideologies of the individuals and groups that comprised the diverse phenomena we collectively label Second Temple Judaism. We are no longer satisfied with delineating the scope of scribal interventions, but want to know who these scribes were, when and where they were active, if and how they communicated with one another, and what sorts of factors influenced their approach to texts. Unfortunately, though, such questions are difficult to answer. We have very little evidence besides the textual products themselves for how Second Temple scribes conceived of their work. These textual products can

\footnotetext{
${ }^{1}$ I am grateful to Jonathan Ben-Dov for many helpful comments on an earlier draft of this article. Of course any errors that remain are mine alone.

${ }^{2}$ There were, of course, exceptions. Abraham Geiger, for example, argued that the numerous variants attested in biblical manuscripts and versions constituted a witness to religious developments within Judaism. See his Urschrift und Uebersetzung der Bibel in ihr Abhängigkeit von der innern Entwicklung des Judenthums (Breslau: Hainauer, 1857).
} 
and do reveal important information about scribal practice. ${ }^{3}$ Nonetheless, it remains exceedingly difficult to confidently identify the social and historical background of concrete cases of textual development.

The Samaritan Pentateuch (SP) has received a great deal of attention recently as a potential source of information about scribal attitudes and scribal practices. Indeed, compared to other witnesses SP seems especially promising in this regard. Its major variants vis-à-vis other known versions are relatively uniform in their mode of construction and in their hermeneutical goals (though exactly how uniform is one of the questions I will raise here). Its latest stage of development can easily be located culturally (if not quite as easily historically), given that it reflects the ideology of the Samaritan community. We also know that, prior to receiving these final Samaritan revisions, this form of the Torah circulated in Judea as well, since it appears at Qumran in pre-Samaritan manscripts like 4QpaleoExod ${ }^{\mathrm{m}}$ and 4QNum ${ }^{\mathrm{b}}$, and served as the basis for a number of other texts. Building on all of this evidence, recent studies of SP and related texts have characterized this pre-SP version of the Torah (not always mutually exclusively) as witnessing a "harmonistic" scribal school, as reflecting a scholarly scribal context similar to that of the Alexandrian scholars of Homer, or as an attempt to underline the prophetic authority of Moses. 4

Though the variants characteristic of the pre-SP Torah certainly deserve an important place in discussions of Second Temple scribal practice, their very uniformity has, I believe, obscured important aspects of the evidence this manuscript tradition presents. I will argue here that we have been too quick to lump all the major changes in the pre-SP Torah together and treat them as a unity (whatever the precise explanation for them), and that we have given too little attention to formally and hermeneutically similar changes that occur in different stages of the

\footnotetext{
${ }^{3}$ On the one hand, D. Carr (Writing on the Tablet of the Heart: Origins of Scripture and Literature [Oxford: Oxford University Press, 2005]) and K. van der Toorn (Scribal Culture and the Making of the Hebrew Bible [Cambridge: Harvard University Press, 2007]) have used comparative data to shed light on the scribal apparatus of pre-exilic Israel and Judah as well as post-exilic Judea; on the other hand, E. Tov provides a window into Second Temple scribal practice through his comprehensive treatment of the evidence of the Qumran scrolls, Scribal Practices and Approaches Reflected in the Texts Found in the Judean Desert (STDJ 54; Leiden: Brill, 2009).

${ }^{4}$ See E. Eshel and H. Eshel, "Dating the Samaritan Pentateuch's Compilation in Light of the Qumran Biblical Scrolls," in Emanuel: Studies in Hebrew Bible, Septuagint, and Dead Sea Scrolls in Honor of Emanuel Tov (ed. S. Paul et al.; Leiden: Brill, 2003), 215-40, and Sidnie White Crawford, "The Pentateuch as Found in the PreSamaritan Texts and 4QReworked Pentateuch," in Changes in Scripture (ed. H. von Weissenberg et al.; BZAW 419; Berlin: De Gruyter, 2011), 123-36; J. Ben-Dov, "Early Texts of the Torah: Revisiting the Greek Scholarly Context," JAJ 4 (2013): 210-34; and M. Kartveit, The Origin of the Samaritans (VTSup 128; Leiden: Brill, 2009), respectively.
} 
manuscript tradition. This has led to a tendency to view SP as attesting to a distinctive scribal approach or school, without adequate attention to what the internal diversity of the SP changes and the broader attestation of such changes in other witnesses might suggest about the scribal culture of early Judaism. The pre-SP Torah is better understood as a particularly concentrated example of a scribal attitude or approach that appears to have been widespread in early Judaism. The evidence further raises questions about the development of the pre-SP Torah and of SP itself, and about the background for the scribal attitude(s) that mark its most characteristic additions.

\section{Internal Diversity of the Major Changes in pre-SP}

When compared to other expanded texts, like MT Jeremiah or some of the 4QReworked Pentateuch manuscripts, the characteristic variants in pre-SP show very little diversity. Aside from two cases of rearrangement or transposition (MT Exod 29:21 is moved to after 29:28, and MT Exod 30:1-10 is moved to after 26:35), all of the major changes involve the repetition of material already present in the Pentateuch. As is well known, pre-SP contains no additions of brand-new material longer than a few words. ${ }^{6}$ Furthermore, these additions of material from elsewhere tend to occur in very specific situations pertaining to certain kinds of speech. They provide evidence that commands are fulfilled and, in a reciprocal move, ensure that later recollections refer to events or words actually documented in the text. ${ }^{7}$

Such apparent singularity of purpose, especially in contrast to the wide variety of alterations preserved in other types of texts, has encouraged the view that all of the major changes in pre-SP likely were introduced in a single editorial moment unless there is concrete evidence to the contrary. ${ }^{8}$ This concrete evidence, to which I will return below, consists of cases where SP itself differs from the pre-SP Qumran manuscripts, either in containing a secondary reading that they lack or vice versa. Aside from these cases, though, the distinctive readings

\footnotetext{
${ }^{5}$ By “pre-SP" I mean the expansive version of the Pentateuch as preserved in SP and in the pre-Samaritan mss from Qumran, without the few specifically Samaritan readings (see further below).

${ }^{6}$ For additions of new material in SP, see the analysis in M. Zahn, Rethinking Rewritten Scripture: Composition and Exegesis in the 4QReworked Pentateuch Manuscripts (STDJ 95; Leiden: Brill, 2011 ), $137-43$.

${ }^{7}$ M. Segal, "The Text of the Hebrew Bible in Light of the Dead Sea Scrolls," Materia Giudaica 12 (2007): 5-20; Zahn, Rethinking, 147-48; Ben-Dov, "Early Texts," 213.

${ }^{8}$ See for example Ben-Dov, "Early Texts," 220, 224; Zahn, Rethinking, 176; Kartveit, Origin, 276, 280 ; E. Tov, "Rewritten Bible Compositions and Biblical Manuscripts, with Special Attention to the Samaritan Pentateuch," DSD 5 (1998): 334-54, at 351; J. Sanderson, An Exodus Scroll from Qumran: 4QpaleoExod ${ }^{M}$ and the Samaritan Tradition (HSS 30; Atlanta: Scholars, 1986), 311.
} 
shared by SP and the pre-SP manuscripts constitute a kind of pre-SP Sondergut that, theoretically at least, could have been introduced all at the same time. As noted, the similarity of the major elements of this layer to one another would seem to support this idea. Yet when this pre-SP Sondergut is examined carefully, it is not as uniform as it appears at first glance. Without denying the generally unified hermeneutical framework that underlies them, I would like to highlight the important degree of diversity that exists even among the characteristic major changes of pre-SP.

The most important issue here is diversity of function. Although all the major changes in pre-SP can appropriately be characterized as in some way meant to increase the internal consistency of the Torah, this happens in different ways. As mentioned, one subset of changes, found only in the plague narrative, inserts notices of command fulfillment that were clearly felt to be missing. In these cases, YHWH tells Moses to do something (usually "speak to Pharaoh"), but in most versions there is no explicit indication that Moses carries out the instruction. In pre$\mathrm{SP}$, the narrative is expanded on the basis of the command to make clear that Moses does everything that YHWH has commanded. ${ }^{9}$

These changes are related, but not identical, to the subset in which the goal is to provide precedents for words or actions later recollected to have taken place. Additions belonging to this subset are not localized in one place like the command fulfillment additions, but are scattered throughout the Torah. They pertain to the recollections of various people (Jacob, Judah, the Israelites, Moses, Eleazar). ${ }^{10}$ Within the group of additions addressing recollections by Moses, we can distinguish those pertaining to the plague narrative (Exod 10:2+//10:3-6; 11:3+//11:4-7), the lawgiving at Sinai (Deut 5,18 // pre-SP Exod 20), the golden calf episode (Deut 9 // pre-SP Exod 32), and the wilderness narratives (Deut 1-3 // pre-SP Exod 18, Num 10-27).

In one striking case, the "recollection" at issue seems to be that of the anonymous pentateuchal narrator. Exodus 39:1 describes the making of priestly vestments: ומן התכלת והארגמן "From the "ותולעת השני עשו בגדי שרד לשרת בקדש ויעשו את בגדי הקדש אשר לאהרן כאשר צוה יהוה את משה blue and purple and scarlet yarns they made finely-worked garments for ministering in the holy place. They made the holy garments that were for Aaron, just as YHWH commanded Moses."

\footnotetext{
${ }^{9}$ See the insertions in SP after Exod 7:18, 29; 8:1, 19; 9:5, 19; 11:3. All of these are extant or can be reconstructed in 4QpaleoExod ${ }^{\mathrm{m}}$; see Sanderson, Exodus Scroll, 197.

${ }^{10}$ Most of these recollections are Moses'; see below as well as the helpful list of major expansions in Kartveit, Origin, 310-12. For the others, see Gen 30:36+//Gen 31:11-13 (Jacob); Gen 42:16+//Gen 44:22 (Judah); Exod 6:9+//Exod 14:12 (Israelites); Num 31:20+//Num 31:21-24 (Eleazar).
} 
But there is no part of the commands for constructing the tabernacle that specifically orders the creation of בגדי שרד, "finely-worked garments," and specifies the materials. That is, in other versions, the making of these בגדים could be interpreted as an act carried out independently of God's instructions. ${ }^{11}$ A scribe who appears to have been bothered by this inserted a corresponding command prior to Exod 27:20: ועשית בגדי תכלת וארגמן ותולעת שני לשרת בהם בקדש, "You shall make garments of blue and purple and scarlet yarns for serving in the holy place." 12 Special notice should be taken of certain major changes that function somewhat differently from these command-fulfillments and recollection-precedents, though on the face of it they appear very similar. Several scholars have made the point recently that it is incorrect to refer to the major characteristic pre-SP changes as "harmonizations."13 While I agree that "harmonization" is not sufficiently precise a term for the command-fulfillments and recollectionprecedents that account for most of the major changes in pre-SP, there are a number of changes

${ }^{11}$ The syntax of Exod 39:1 is somewhat ambiguous. It is possible to interpret 39:1a as a heading introducing the long section on Aaron's vestments, with the waw on ויעשו serving an explicative function. If this is the case, then the בגדי שרד of 1a are identical to the items whose making is described in the rest of the chapter: "From the blue and purple and crimson they made finely worked garments; that is, they made the holy garments which were for Aaron" (the ephod, breastpiece, robe, etc.). This interpretation is supported by the brief notices on

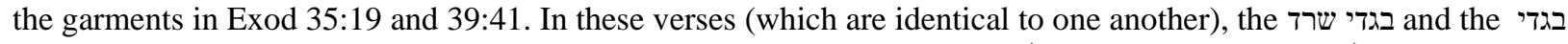
את בגדי השרד לשרת בקדש את בגדי הקדש לאהרן : stand in apposition, implying that they refer to the same garments "the finely-worked garments for serving in the holy place; the holy garments for Aaron the priest and the garments of his sons to act as priests." It seems, however, that the scribe responsible for the pre-SP addition interpreted the בגדי שרד of 39:1 as some other item, additional to Aaron's vestments (thus with a simple coordinating waw: “...they made finely worked garments..., and they made the holy garments...”). Evidence for this is the placement of the addition after 27:19, separated from the section on Aaron's vestments that begins in 28:1. Although Sanderson maintains that this placement is simply a mistake (Exodus Scroll, 209-10), the correspondence between 27:18 and the verse immediately preceding 39:1 (i.e., 38:31) suggests otherwise.

${ }^{12}$ It is not clear why this scribe did not include the word שרד in most cases, added precedents in SP match their later recollections as closely as possible. Perhaps a desire to deploy the standard locution וערית led the scribe to

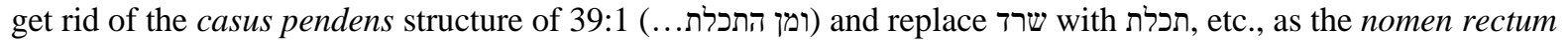
following the construct בגדי (ברד could have been retained even in a sentence beginning with ועיעית.

In a recent article, Tov classifies this addition as a simple harmonization, different in nature from the characteristic "editorial interventions" of pre-SP. I would argue, though, that the insertion of an entire command here and in one other case Tov lists (Exod 40:11 MT 4QpaleoExod ${ }^{\mathrm{m}}$ SP, absent in LXX) is likely to function differently from his many other examples of harmonization. It does not simply coordinate the language of two parallel passages, but addresses a situation where a command is perceived as absent altogether. Thus, it addresses a gap in the command section by providing the necessary precedent for the actions taken later in the description of the commands' execution. As such, these insertions function in precisely the same way as larger cases of missing commands corrected in pre-SP, such as Exod 10:3-6; 11:4-7; Num 31:21-24. See E. Tov, "The Samaritan Pentateuch and the Dead Sea Scrolls: The Proximity of the Pre-Samaritan Qumran Scrolls to the SP," in Keter Shem Tov: Collected Essays on the Dead Sea Scrolls in Memory of Alan Crown (ed. I. Young and S. Tzoref; Piscataway, NJ: Gorgias Press, 2011), 59-88, at 71.

${ }^{13}$ See Tov, "Rewritten Bible Compositions," 340; A. Rofé, "Historico-Literary Aspects of the Qumran Biblical Scrolls," in The Dead Sea Scrolls Fifty Years After Their Discovery (ed. L.H. Schiffman et al.; Jerusalem: Israel Exploration Society, 2000), 30-39, at 31; Segal, "Text of the Hebrew Bible," 16; Kartveit, Origins, 275-76; Zahn, Rethinking, 147; Ben-Dov, "Early Texts," 221. 
that do seem to be best described as harmonizations. The transpositions in the Tabernacle materials mentioned above are a good example. The reason Exod 29:21 is relocated after v. 28 is in order to conform the sequence of the instructions for the installation of the high priest to the sequence in which the carrying out of those instructions is given in Leviticus 8.

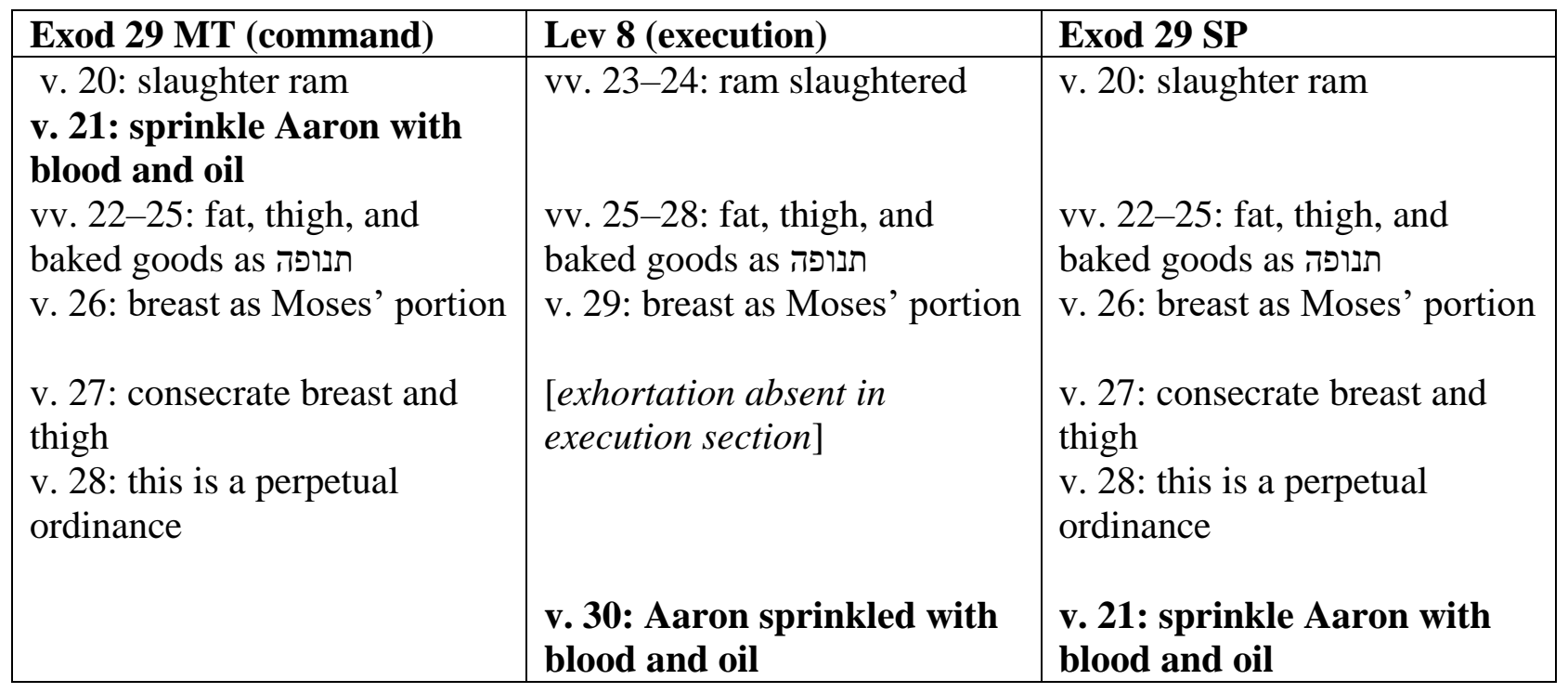

This is harmonization in its most basic sense: one passage is adjusted to conform more closely to a second, parallel passage. It is not that the command or fulfillment is missing, as is the case in the plague narratives, but that, on the literary level, the elements of the command and fulfillment are presented differently. The same impetus seems to lie behind the relocation of the instructions for the incense altar from Exod 30 to Exod 26, though here the discrepancies in sequence between command and fulfillment are not entirely resolved. ${ }^{14}$

Two other clear cases of harmonization in pre-SP reverse the more common procedure of inserting material from Deuteronomy into Exodus and Numbers. Numbers 20:14a, 17-18 are inserted after Deut 2:7, and the wilderness itinerary in Deut 10:6-7 is expanded and revised to bring it into conformity with Num 33:31-37. ${ }^{15}$ In the other cases (of importation from Deuteronomy to Numbers), the issue is not harmonization as much as a need to create

\footnotetext{
${ }^{14}$ More details are presented by Zahn, Rethinking, 159-60.

15 Deut 10:6-9 preserves a bit of wilderness itinerary that interrupts Moses' recollections of his second stay on Sinai/Horeb (Deut 10:1-5, 10). The itinerary bears some resemblance to Num 33:31-37, but recounts only 4 stops (Numbers has 8), and has the first two locations in the reverse order. Most significantly, according to Deut 10:6 (MT/LXX) Aaron dies in Moserah, the second stop in the itinerary (first stop in Num 33:31). In Numbers, however, Aaron dies at Mt. Hor (33:38 and 20:23-29), the eighth stop in this section of the itinerary. This substantial discrepancy in content is removed via the revisions in SP.
} 
tetrateuchal precedent for Moses' recollections in Deuteronomy. ${ }^{16}$ But these moves in the opposite direction, from Numbers to Deuteronomy, seem aimed more directly to harmonize the two accounts; to increase the degree of correspondence between them.

Finally, even though most of the largest changes in pre-SP can be attributed to the very specific goals mentioned above, several changes of more moderate scope address issues of narrative continuity or the text's self-referentiality in a broader range of ways. For example, the Urim and Thummim appear out of nowhere in Exod 28:30, where God instructs that they should be placed into the breastplate of the high priest. In SP this sudden apparition is explained by the insertion both of a command to make the Urim and the Thummim and of a notice (later on, after Exod 39:21) that the command was carried out. ${ }^{17}$ Another pair of revisions addresses coherence in a much different way. The MT/LXX versions of Gen 10:19 and Deut 34:1-3 each contain long, detailed descriptions of the promised land, rich with obscure place-names. In SP both of these passages are replaced with a standardized formulation drawn from elsewhere in Genesis and Deuteronomy: "From the river of Egypt as far as the Great River, the river Euphrates, and as far as the western sea" (cf. Gen 15:18; Deut 11:24).

Most of the major changes in the pre-SP Sondergut certainly represent two narrow and related concerns, fulfillment of commands and precedent for recollections. Yet this "layer" of changes also encompasses alterations with other ways of addressing issues of coherence and selfreferentiality - it cannot be reduced to the narrowly focused changes that have received most attention in scholarship. That the pre-SP Sondergut preserves several different modes for increasing the Torah's self-referentiality suggests a rethinking of our models for how this pre-SP text was produced. This is especially true when the internal evidence of pre-SP is combined with manuscript evidence for additional stages of transmission, to which I now turn.

\section{Diverse Origins for Major Coordinating Changes}

As noted, the narrow focus of most of the major revisions attested in pre-SP has often led to the conclusion that they most likely constitute a single editorial layer introduced at a single point in time. This chain of argument creates the impression that such changes are unique to this pre-SP Sondergut. In fact, however, functionally identical changes are attested at other stages of

\footnotetext{
16 Segal, "Text of the Hebrew Bible," 16-17.

17 The second addition is attested in 4QExod-Lev ${ }^{\mathrm{f}}$, which is not extant prior to Exod 38 and thus does not preserve the first addition.
} 
transmission, in contexts that must have both predated and postdated the formation of pre-SP (however that might have occurred). And if we broaden the scope beyond just commandfulfillment and recollection-precedent as strictly defined above - in line with the true diversity of the pre-SP materials - even more parallels emerge. For the sake of argument, I restrict myself here to parallels explicitly attested in extant manuscripts and versions, though it is worth noting that scholars have often reconstructed similar changes in earlier stages of the transmission of the Pentateuch and other biblical books.

\section{a. changes identical to the pre-SP coordinating additions}

Many of the pre-SP changes function to provide the appropriate precedent in the Tetrateuch for Moses' recollections in Deut 1-3, 5, and 9. Yet the process of coordinating the relevant texts of Exodus and Numbers with their ostensible recollection in Deuteronomy must have begun earlier. It has in fact been proposed that an early version of the Hexateuch was created in part by importing text from Deuteronomy into previously independent versions of what are now Exodus and Numbers. ${ }^{18}$ More to the point, there is concrete evidence of this process in Exod 32:9. This verse, present in MT, 4QpaleoExod ${ }^{\mathrm{m}}$, and SP, is absent in most Greek witnesses, including the major $4^{\text {th }}$ and $5^{\text {th }}$ c. codices. ${ }^{19}$ Its contents exactly match Deut 9:13, aside from the expected difference in speaker. The match with Deuteronomy strongly suggests that the verse is a secondary, coordinating insertion. ${ }^{20}$ Thus Exod 32:9 is the first documented stage of a process of providing precedent in the Exodus narrative for Moses' version of the golden calf episode. This process is witnessed more fully in SP/4QpaleoExod ${ }^{\mathrm{m}}$, in which material from Deut 9:20 is inserted after Exod 32:10.

\begin{tabular}{|c|c|c|c|}
\hline LXX Exod 32:(9)-11 & MT Exod 32:9-11 & $\begin{array}{l}\text { SP/4QpaleoExod } \\
\text { Exod 32:9-11 }\end{array}$ & Deut 9:13, 20 \\
\hline \multirow{7}{*}{ 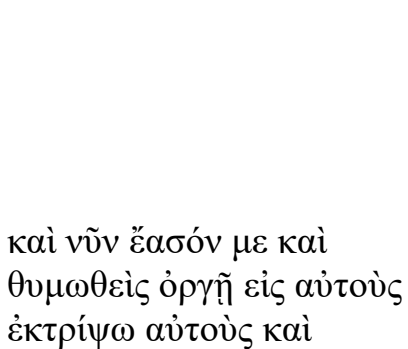 } & ויאמר יהוה אל משה & ויאמר יהוה אל משה & ויאמר יהוה אלי לאמר \\
\hline & ראיתי את העם הזה והנה & ראיתי את העם הזה והנה & ראיתי את העם הזה והנה \\
\hline & עם קשה ערף הוא & עם קשה ערף הוא ועתה & עם קשה ערף הוא \\
\hline & ועתה הניחה לי ויחר אפי & הניחה לי ויחר אפי בם & \\
\hline & בהם ואכלם ואעשה אותך & ואכלם ואעשה אתך לגוי & \\
\hline & לגוי גדול & 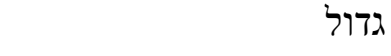 & \\
\hline & & ובאהרן התאנף יהוה מאד & ובאהרן התאנף יהוה מאד \\
\hline
\end{tabular}

${ }^{18}$ D. Carr, The Formation of the Hebrew Bible: A New Reconstruction (Oxford: Oxford University Press, 2011), 260. See also Rofé, "Historico-Literary Aspects," 32.

${ }^{19}$ As demonstrated by the apparatus to the Göttingen Septuagint.

${ }^{20}$ Carr, Formation, 103; contra Rofé, "Historico-Literary Aspects," 33.

${ }^{21}$ The Hebrew text of SP follows A. Tal and M. Florentin, The Pentateuch: The Samaritan Version and the Masoretic Version (Tel Aviv: TAU Press, 2010). 


\begin{tabular}{|c|c|c|c|}
\hline 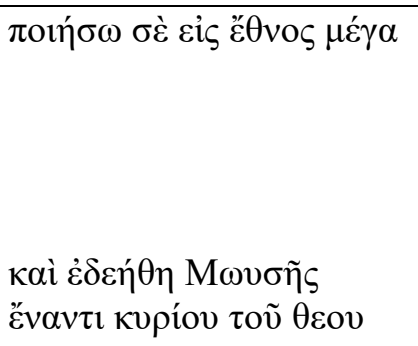 & אלהיו ... אשה את פני יהוה & 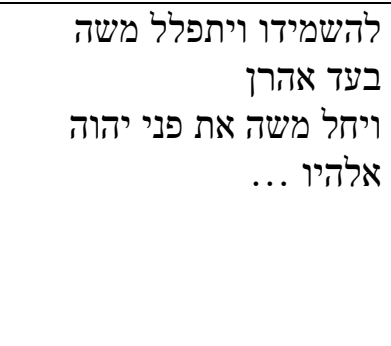 & להשרמידו ואתפלל ההוא בעד \\
\hline $\begin{array}{l}\text { "So now, leave me alone, } \\
\text { and I will be wrathfully } \\
\text { angry with them and } \\
\text { destroy them, and I will } \\
\text { make you into a great } \\
\text { nation." } \\
\text { And Moses beseeched } \\
\text { the Lord God... }\end{array}$ & $\begin{array}{l}\text { YHWH said to Moses, } \\
\text { "I have seen this } \\
\text { people, and indeed, it is } \\
\text { a stiff-necked people. } \\
\text { So now, leave me alone } \\
\text { so that my anger can } \\
\text { flare up against them } \\
\text { and consume them, and } \\
\text { I will make you into a } \\
\text { great nation." } \\
\text { And Moses beseeched } \\
\text { YHWH his God... }\end{array}$ & $\begin{array}{l}\text { YHWH said to Moses, } \\
\text { "I have seen this } \\
\text { people, and indeed, it is } \\
\text { a stiff-necked people. } \\
\text { So now, leave me alone } \\
\text { so that my anger can } \\
\text { flare up against them } \\
\text { and consume them, and } \\
\text { I will make you into a } \\
\text { great nation." } \\
\text { And at Aaron too } \\
\text { YHWH was so angry as } \\
\text { to destroy him, so } \\
\text { Moses prayed on } \\
\text { Aaron's behalf. } \\
\text { And Moses beseeched } \\
\text { YHWH his God... }\end{array}$ & $\begin{array}{l}\text { YHWH said to me, "I } \\
\text { have seen this people, } \\
\text { and indeed, it is a stiff- } \\
\text { necked people." } \\
\text { And at Aaron too } \\
\text { YHWH was so angry as } \\
\text { to destroy him, so I } \\
\text { prayed also on Aaron's } \\
\text { behalf at that time. }\end{array}$ \\
\hline
\end{tabular}

Another case pertaining to precedent is found in Exod 40:11, which like the previous example is extant in MT, 4QpaleoExod ${ }^{\mathrm{m}}$, and SP, but absent in LXX. Here the expanded text provides the missing command corresponding to an act carried out later on in the text: Lev 8 describes Moses anointing the basin and its stand as part of the consecration of the Tabernacle, but the command in Exod 40 (LXX) makes no mention of anointing the basin.

\begin{tabular}{|c|c|c|}
\hline Exod 40:10(-11) LXX & Exod 40:10-11 MT 4Q SP & Lev 8:11 \\
\hline 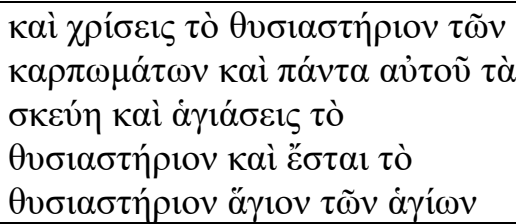 & 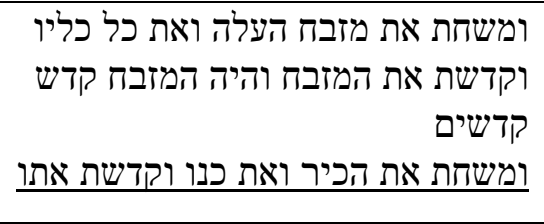 & וימשח את המזבח ואת ואב כל כליו \\
\hline $\begin{array}{l}\text { You shall anoint the altar of } \\
\text { burnt offering and all of its } \\
\text { vessels, and you shall sanctify } \\
\text { the altar and the altar shall be } \\
\text { most holy. }\end{array}$ & $\begin{array}{l}\text { You shall anoint the altar of } \\
\text { burnt offering and all of its } \\
\text { utensils, and you shall sanctify } \\
\text { the altar and the altar shall be } \\
\text { most holy. } \\
\text { And you shall anoint the basin } \\
\text { and its stand and sanctify it. }\end{array}$ & $\begin{array}{l}\text { He sprinkled some of it upon the } \\
\text { altar seven times, and he } \\
\text { anointed the altar and all its } \\
\text { utensils, } \\
\text { and the basin and its stand, to } \\
\text { sanctify them. }\end{array}$ \\
\hline
\end{tabular}


In pre-SP, all the instances of providing a missing fulfillment to a command occur in the plague narrative (Exod 7-11). The most precisely parallel case in a different context occurs in the version of the Sinai pericope preserved in 4Q158 (4QReworked Pentateuch A). ${ }^{22}$ This text attests further revisions of various types to a base text quite like 4QpaleoExod ${ }^{\mathrm{m}} .{ }^{23}$ In fact, the plus in 4Q158's version of Exod 20 reacts specifically to the pre-SP form of the text, into which has been inserted from Deut 5:30-31 God's instruction to Moses, "Go, tell them, return to your tents. But you stand here with me...". In this pre-SP version of Exodus, there is no record that Moses fulfills this command (in part because God doesn't give him the chance to, instead launching right into the Covenant Code). ${ }^{24}$ But in 4Q158, material has been inserted that makes clear that Moses did indeed go and dismiss the people. Thus, a comparison of 4Q158 with $\mathrm{SP} / 4 Q$ paleoExod ${ }^{\mathrm{m}}$ reveals multiple levels of revision and expansion of the Sinai pericope-a process that almost certainly began earlier, in stages of composition that can no longer be documented in the manuscript evidence. ${ }^{25}$

\begin{tabular}{|c|c|}
\hline Exod 20:21b-22 (SP; cf. Deut 5:30-31) ${ }^{26}$ & 4Q158 frag. 7, lines 3-5 \\
\hline 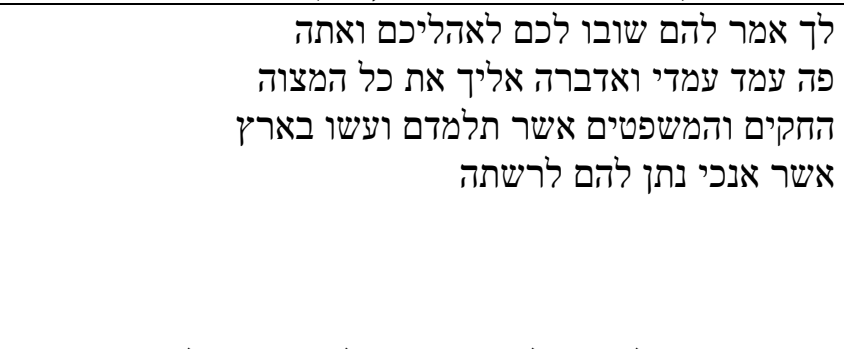 & 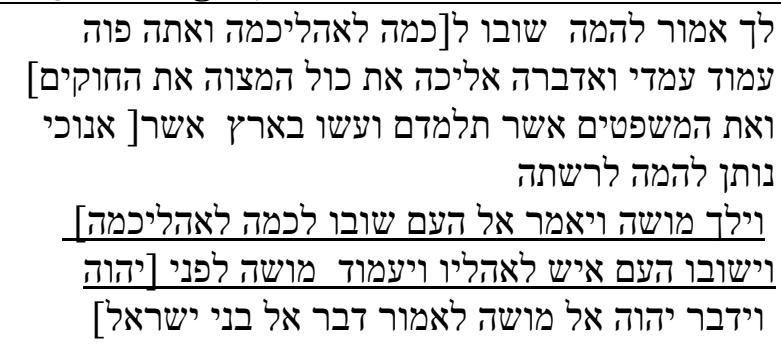 \\
\hline וידבר יהוה אל משה לאמור דבר אל בני ישראל & \\
\hline $\begin{array}{l}\text { Go, tell them, "Return to your tents." But you, stand } \\
\text { here with me, so that I can tell you the whole } \\
\text { commandment, the statutes and the ordinances, that } \\
\text { you shall teach them to do in the land which I am } \\
\text { giving to them to inherit. }\end{array}$ & $\begin{array}{l}\text { Go, tell them, "Return to [your tents." But you, } \\
\text { stand here with me, so that I can tell you the } \\
\text { whole commandment, the statutes] and the } \\
\text { ordinances, that you shall teach them to do in the } \\
\text { land which [I am giving to them to inherit. }\end{array}$ \\
\hline
\end{tabular}

${ }^{22}$ Another possible example would be the substantially different versions of Exod 36-39, the "fulfillment section" of the tabernacle account, preserved in LXX and MT. The unit as a whole, Exod 25-40, seems to have undergone several rounds of expansion and development. In this context, the LXX of chs 36-39 appears to represent an earlier form of the fulfillment section than the MT, which has been expanded in order to ensure that each instruction given in the command section is explicitly matched by a fulfillment. See A. Aejmelaeus, "Septuagintal Translation Techniques: A Solution to the Problem of the Tabernacle Account," in Septuagint, Scrolls and Cognate Writings (ed. G. J. Brooke and B. Lindars; SBLSCS 33; Atlanta: Scholars, 1992), 381-402.

${ }^{23}$ See Zahn, Rethinking, 25-74.

${ }^{24}$ Zahn, Rethinking, 39.

${ }^{25}$ Christoph Berner analyzes several aspects of the present MT text of Exod 19-20 as redactional elements that respond to the parallel account in Deut 5. For example, he suggests that Exod 20:19 was inserted in order to allude to the "more elaborate account of the people's request for a mediator" in Deut 5; see C. Berner, "The Redaction History of the Sinai Pericope (Exod 19-24) and its Continuation in 4Q158," DSD 20 (2013): 378-409, at 385 .

\footnotetext{
${ }^{26}$ This section of 4 QpaleoExod ${ }^{\mathrm{m}}$ is not preserved.
} 
YHWH spoke to Moses saying: "Say to the children of Israel..."

So Moses went and said to the people, "Return to your tents, ”] and the people returned, each to his tent, and Moses stood before [YHWH.

YHWH spoke to Moses saying: "Say to the children of Israel...”]

Another possible example is preserved in $4 \mathrm{QNum}^{\mathrm{b}}$ and in LXX, but not in MT or SP. It differs from the foregoing in that Balaam, rather than God, is the speaker of the instruction. Otherwise, it is precisely the same: the formulation of the instruction provides the wording for the addition, which indicates that both Balak and Balaam did as Balaam had proposed. The interpretation of this example must remain somewhat uncertain given that conditions are good for an eyeskip (וילך ד וילך). But given the "work" done by the plus and the parallels to other revisionary additions elsewhere, purposeful addition seems at least as likely. ${ }^{27}$

\begin{tabular}{|c|c|}
\hline Num 23:3 MT (= SP) & Num 23:3 4QNum ${ }^{b}(\approx G)^{28}$ \\
\hline ויאמר בלעם לבלק התיצב על עלתך & ויואמר בלעם אל בלק התיצב על ע]ולתכה ואנוכי אלך \\
\hline ואלכה אולי יקרה יהוה לקראתי ודבר מה יראני והגדתי & א'לי יקרה אלוהים [לקראתי ודבר מה יראני והגד]תי \\
\hline לך & ל[כה ו]ילך ויתיצב בלק על ע[ו]לתו ובלעם [נקרה אל \\
\hline 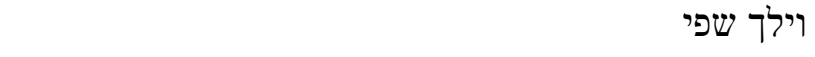 & 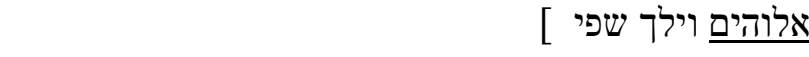 \\
\hline $\begin{array}{l}\text { Balaam said to Balak, "You stand here by your burnt } \\
\text { offering, while I go on; perhaps YHWH will come to } \\
\text { meet me, and whatever he shows me I will tell you." } \\
\text { So he went on to a height. }\end{array}$ & $\begin{array}{l}\text { [Balaam said to Balak, "You stand here by] your [b]urnt } \\
\text { offering, while I myself go on; perhaps God will come } \\
\text { [to meet me, and whatever he shows me] I will [tell] } \\
\text { y[ou." So] Balak went and stood by his b[u]rnt offering, } \\
\text { and Balaam [went to meet God; he went on to a height ] }\end{array}$ \\
\hline
\end{tabular}

\section{b. Similar but not identical changes}

Besides these examples that are structurally identical to changes in pre-SP, there is also ample evidence for scribal changes that address issues of self-referentiality and consistency in a broader range of ways. ${ }^{29}$ A few examples will serve to make the point here. ${ }^{30}$ First, a

${ }^{27}$ See also the Lucianic Greek text of 1 Sam 9:3, where Kish's instructions to Saul become the basis for an addition noting that Saul did just what his father said. (I am grateful to Jonathan Ben-Dov for this reference.) On the significance of this and other potentially early elements in the Lucianic text of Reigns, see E. Tov, "Lucian and Proto-Lucian: Toward a New Solution of the Problem," in The Greek and Hebrew Bible: Collected Essays on the Septuagint (VTSup 72; Leiden: Brill, 1999), 477-88.

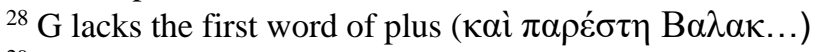

${ }^{29}$ Ben-Dov ("Early Texts," 213) traces such an interest in consistency back to the pentateuchal priestly narratives, which show sustained interest in demonstrating Moses' compliance with God's commands, though not deploying "technical duplication" to the same extent as SP.

${ }^{30}$ 4Q158 is an especially rich source of further examples; see M. Zahn, "Building Textual Bridges: Towards an Understanding of 4Q158 (4QReworked Pentateuch A)," in The Mermaid and the Partridge: Essays from the Copenhagen Conference on Revising Texts from Cave Four (ed. G.J. Brooke and J. Høgenhavn; STDJ 96; Leiden: Brill, 2011), 13-32. 
modification preserved in SP Num 25:4-5 (but absent in 4QNum ${ }^{\mathrm{b}}$, thus pointing to a different origin from the changes in the pre-SP Sondergut), addresses an issue very similar to the command-fulfillment additions in pre-SP. It differs slightly, however, in that in this case the record of fulfillment is not absent; instead, Moses responds to God's command, but does something other than what God told him to do. As a result, the change takes the form not of addition (as in the cases of missing fulfillments), but of replacement, as God's original command is replaced with a new version corresponding to Moses' action.

\begin{tabular}{|c|c|}
\hline Num 25:4-5 MT (= 4QNum $\left.{ }^{b}\right)$ & Num 25:4-5 SP \\
\hline ויאמר יהוה אל משה קח את כל ראשי העם והוקע אותם & ויאמר יהוה אל משה אמר ויהרגו את האנשים הנצמדים \\
\hline ליהוה נגד השמש וישב חרון אף יהוה מישראל & לבעל פעור וישוב חרון אף יהוה מישראל \\
\hline ויאמר משה אל שפטי ישראל הרגו איש אנשיו הנצמדים & ויאמר משה אל שפטי ישראל הרגו איש את אנשיו \\
\hline לבעל פעור & הנצמדים לבעל פעור \\
\hline $\begin{array}{l}\text { YHWH said to Moses, "Take all the leaders of the } \\
\text { people and have them impaled for YHWH in broad } \\
\text { daylight, so that the wrath of YHWH's anger might } \\
\text { turn away from Israel." } \\
\text { So Moses said to the judges of Israel, "Each man of } \\
\text { you, kill those of your men who have attached } \\
\text { themselves to Ba'al Pe'or!" }\end{array}$ & $\begin{array}{l}\text { YHWH said to Moses, "Order them to kill those } \\
\text { men who have attached themselves to Ba'al Pe'or, } \\
\text { so that the wrath of YHWH's anger might turn } \\
\text { away from Israel." } \\
\text { So Moses said to the judges of Israel, "Each man of } \\
\text { you, kill those of your men who have attached } \\
\text { themselves to Ba'al Pe'or!" }\end{array}$ \\
\hline
\end{tabular}

An addition that more than anything else resembles the pre-SP additions pertaining to the creation of the Urim and Thummim is preserved in SP and LXX of Num 4:14. ${ }^{31}$ (Again, the presence of this plus in LXX as well as SP separates it from the pre-SP Sondergut considered above.) In the instructions in Num 4 regarding how Aaron and his sons should prepare the Tabernacle for travel when the Israelites break camp, the main objects in the tabernacle and its court are mentioned, including the ark, the table, the lampstand, the incense altar, and the altar of burnt offering (Num 4:5-14). But no mention is made of the basin (הכיור) and its stand (see Exod $30: 18 ; 38: 8)$. A scribe must have reasoned that of course the basin and its stand would have to be covered for travel just like the other furniture, so in SP and LXX a command to do exactly this is inserted after Num 4:14. The new command is formulated using language that was used earlier in the chapter, particularly in the command to cover the incense altar in vv. 9-10:32

\footnotetext{
314 QNum ${ }^{\mathrm{b}}$ is not extant at this point, so it is impossible to say whether it also contained this reading.

${ }^{32}$ Cf. Kartveit (Origin, 311), who views Num 4:13f and Exod 31:9 as the sources for the formulation. While Exod 31:9 does contain the phrase את הכיור ואת כנו, Num 4:13-14 share few words with the addition. To my mind, the more extensive connections of wording with Num 4:9-10 make those verses a more likely model. Kartveit's comment (Origin, 279) that this addition reflects the same exegetical principle as the insertion of missing executions in Exod 6-11 (in both cases, "God's commands are truthfully transmitted and executed by Moses") does not account for the significant differences between the two loci, nor the presence of the Num 4:14 addition in LXX
} 


\begin{tabular}{|c|c|c|}
\hline MT Num 4:14 & SP Num 4:14 (= LXX) & MT Num 4:9-10 \\
\hline עור תחש ושמו בדיו המזח ופרשו עליו כסוי & 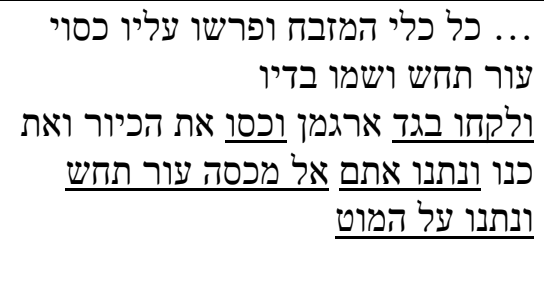 & 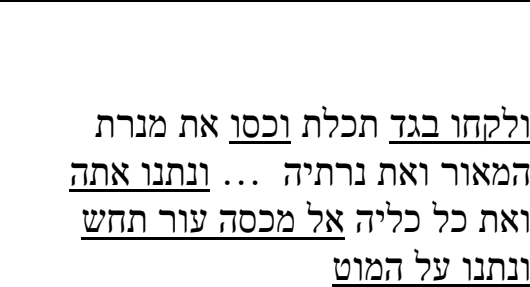 \\
\hline $\begin{array}{l}\text {...all the utensils for the altar, } \\
\text { and they shall spread over it a } \\
\text { covering of fine leather, and put } \\
\text { in place its poles. }\end{array}$ & $\begin{array}{l}\text {...all the utensils for the altar, } \\
\text { and they shall spread over it a } \\
\text { covering of fine leather, and put } \\
\text { in place its poles. } \\
\text { They shall take a purple cloth } \\
\text { and cover the basin and its stand, } \\
\text { and they shall put it into a cover } \\
\text { of fine leather, and put it on the } \\
\text { carrying-frame. }\end{array}$ & $\begin{array}{l}\text { They shall take a blue cloth and } \\
\text { cover the lampstand for the light, } \\
\text { and its lamps... and they shall } \\
\text { put it and all its utensils into a } \\
\text { cover of fine leather, and put it } \\
\text { on the carrying-frame. }\end{array}$ \\
\hline
\end{tabular}

One final example pertains to the Shabbat commandment in the Decalogue. As a glance at any critical apparatus indicates, the two versions of the Decalogue (Exod 20:2-17; Deut 5:621) attracted a great deal of attention from scribes who attempted to smooth the discrepancies between them. ${ }^{33}$ By far the largest such discrepancy, of course, is the two different rationales given for the command to observe Shabbat. According to Exod 20, the Israelites are to keep Shabbat because God rested on the seventh day of creation, while according to Deut 5, Shabbat memorializes the exodus from Egypt. Two different attempts to reconcile this discrepancy are attested in manuscripts of Deuteronomy's Decalogue. In the Nash Papyrus and in two phylacteries and one mezuzah from Qumran, the expected deuteronomic rationale appealing to the exodus from Egypt is replaced by the creation rationale from Exod 20. On the other hand, in

as well as SP. Here the issue is not a missing fulfillment or even a "missing" command that is later carried out, but a logical gap in Moses' command: the basin and its stand have been manufactured (Exod 38:8), but no provision is made for their subsequent transportation.

${ }^{33}$ Many of these are charted by Eshel and Eshel, "Dating," 233-35 (the LXX provides several additional examples). Note, however, that the broad and sporadic attestation of these harmonizations does not support their model of an essentially linear development of "harmonistic" texts, according to which the manuscripts containing major harmonizations (such as the Nash Papyrus and 4QDeut ${ }^{\mathrm{n}}$ ) also contain all of the more minor harmonizations (ibid., 234). In fact, the texts with the major harmonizations differ a great deal among themselves with regard to how many and which of the more minor harmonizations they contain. 
4QDeut ${ }^{\mathrm{n}}$ and in Codex Vaticanus of the LXX, the creation rationale is inserted alongside the one that appeals to the exodus from Egypt. ${ }^{34}$

There is a sense in which the two versions of the Decalogue present issues of recollection-precedent just like those seen in pre-SP. After all, the Deut 5 version is presented as Moses' recollection of the earlier revelation at Horeb (Deut 5:4-5). But insofar as these adjustments are made to the Deuteronomy version, the issue is not the narrow concern with precedent for Moses' words that is so frequent in pre-SP. Instead, like the occasional pre-SP insertion of tetrateuchal materials into Deuteronomy, they seem to be prompted by a more general harmonistic impulse to bring the two parallel units into greater coordination. ${ }^{35}$

\section{The Samaritan $10^{\text {th }}$ Commandment}

An especially significant instance of a change similar in structure and motivation to the pre-SP coordinating additions is the additional commandment concerning the building of an altar on Mt. Gerizim that appears in SP at the end of both versions of the Decalogue. This addition, which of course reflects the Samaritan community's belief in the legitimacy of their temple on Mt.

Gerizim, is absent from 4QpaleoExod ${ }^{\mathrm{m}}$ and other Qumran manuscripts. It therefore must have had a different origin from the other coordinating additions, and it seems clear that this must have been one of a very few truly "sectarian" changes that the Samaritans made to their text of the Pentateuch. On the other hand, it is constructed just like the distinctive pre-SP additions, out of existing material from elsewhere in the Pentateuch — in this case, Deut 11:29a; 27:2b, 3a, 4-7; 11:30. ${ }^{36}$ Although its "sectarian" nature might lead us to believe that this is simply mimicry of an existing compositional technique for different ideological purposes, closer examination reveals that, in fact, this insertion reflects a hermeneutical outlook very similar to what we find in the pre-SP coordinating additions.

\begin{tabular}{|c|c|c|}
\hline Exod 20:13 (17) MT & $\begin{array}{l}\text { Exod 20:13 (17) SP } \\
\text { (compare Deut 5:17 [21] SP) }\end{array}$ & Deut 11 and $27(S P \approx M T)$ \\
\hline לא תחמד בית רעך ... וכל אשר & לא תחמד בית רעך ... וכל אשר & \\
\hline
\end{tabular}

${ }^{34}$ Eshel and Eshel, "Dating," 234-35. Note that the creation rationale is inserted in different places in Vaticanus and 4QDeut ${ }^{\mathrm{n}}$.

${ }^{35}$ Contra Ben-Dov, I do not think that these changes should be understood as "legal" ("Early Texts," $221 \mathrm{n}$. 39). The issue is not one of law but of literary and conceptual coordination of parallels. This is especially clear since the changes pertain to the rationale for the law, not the law itself.

${ }^{36}$ See also Crawford, "Pentateuch as Found," 133. 


\begin{tabular}{|c|c|c|}
\hline לרעך & 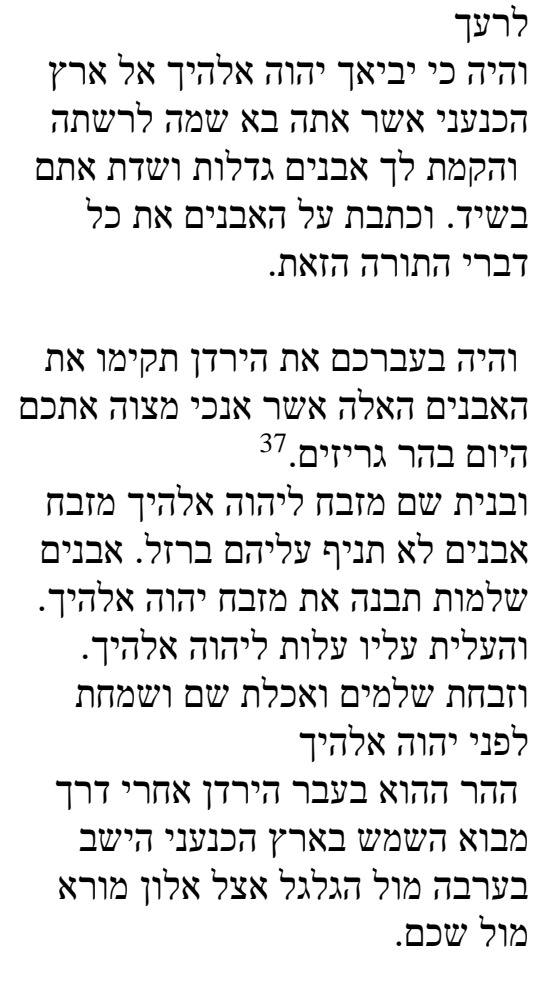 & 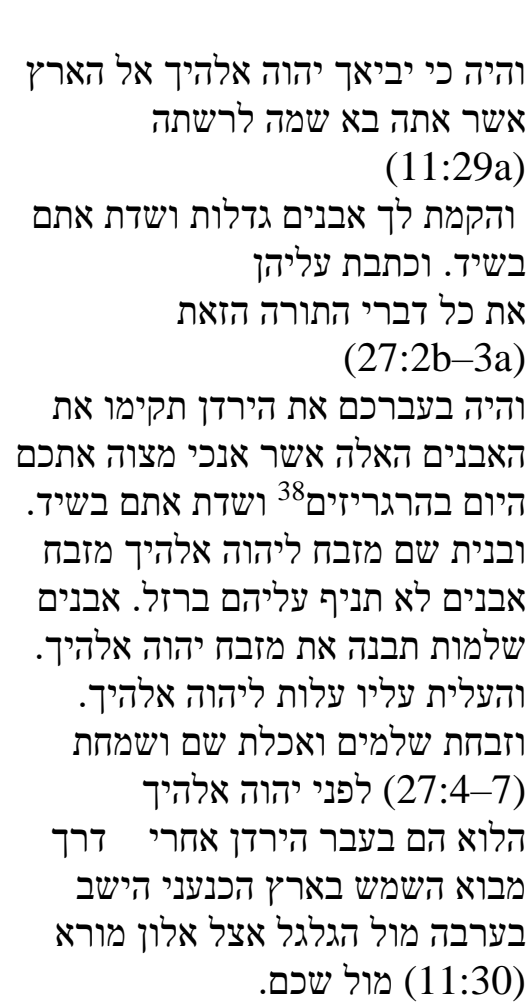 \\
\hline $\begin{array}{l}\text { Do not covet your neighbor's } \\
\text { house...or anything that belongs } \\
\text { to your neighbor. }\end{array}$ & $\begin{array}{l}\text { Do not covet your neighbor's } \\
\text { house...or anything that belongs } \\
\text { to your neighbor. } \\
\text { When YHWH your God brings } \\
\text { you to the land of the Canaanites } \\
\text { into which you are entering to } \\
\text { inherit it, you shall set up for } \\
\text { yourself large stones and cover } \\
\text { them with whitewash. And you } \\
\text { shall write upon the stones all the } \\
\text { words of this Torah. } \\
\text { And when you cross } \\
\text { over the Jordan, you shall set up } \\
\text { these stones that I am } \\
\text { commanding you about today on } \\
\text { Mt. Gerizim. And you shall build } \\
\text { there an altar to YHWH your }\end{array}$ & $\begin{array}{l}\text { When YHWH your God brings } \\
\text { you to the land of the Canaanites } \\
\text { into which you are entering to } \\
\text { inherit it (11:29a), you shall set } \\
\text { up for yourself large stones and } \\
\text { cover them with whitewash. And } \\
\text { you shall write upon the stones } \\
\text { all the words of this Torah } \\
\text { ( } 27: 2 b-3 a) \text {. And when you cross } \\
\text { over the Jordan, you shall set up } \\
\text { these stones that I am } \\
\text { commanding you about today on } \\
\text { Mt. Gerizim. And you shall build } \\
\text { there an altar to YHWH your }\end{array}$ \\
\hline
\end{tabular}

${ }^{37}$ In the manuscript (Shechem 6) that forms the basis for Tal and Florentin's diplomatic edition, הר גריזים is written as two words here in Exodus, though in the reading tradition it is pronounced as a single word (Tal and Florentin, Pentateuch, 740), and Von Gall's apparatus indicates that many other manuscripts write הרגריזים as a single word, as in Deut 27:4 (A. F. von Gall, Der Hebräische Pentateuch der Samaritaner [Giessen: Töpelmann, 1918]).

${ }^{38}$ MT instead of בהר עיבל reads, "on Mt. Ebal." This reading is generally agreed to constitute a tendentious revision meant to counter Samaritan claims about Mt. Gerizim (see e.g. Kartveit, Origin, 302-3;

Knoppers, Jews and Samaritans, 203, 210). Thus, Deuteronomy would originally have referred to an altar on Mt. Gerizim, not on Mt. Ebal. This original reading is now attested in a small fragment of Deuteronomy that is claimed to have come from Qumran Cave 4; see J. H. Charlesworth, "What is a Variant? Announcing a Dead Sea Scrolls Fragment of Deuteronomy," Maarav 16 (2009): 201-12 + Plates ix-x (273-74). 


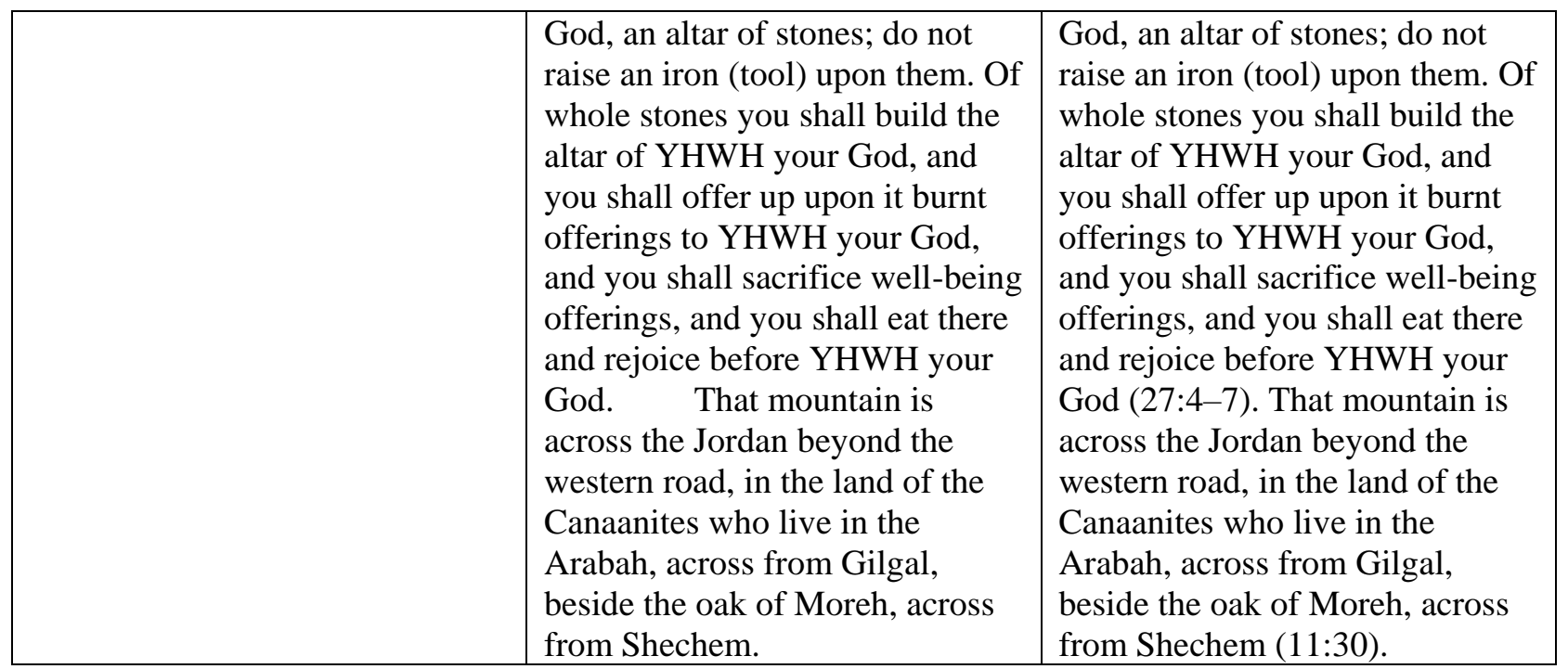

To be sure, the situation is not exactly the same. Unlike the other additions from Deuteronomy in the Samaritan text of Exod 20, there is no explicit indication in Deuteronomy that these words were originally spoken by God at Sinai. But with the help of Gary Knoppers's new very sensitive construal of how the Torah might have been read from a Samaritan perspective, we are able to see why Samaritan scribes might have felt that the altar commandment belonged in the Sinai pericope. ${ }^{39}$

The key lies in the way the Covenant Code's altar law in Exod 20:24-26 was read. As Knoppers indicates, this law must have been read early on in conjunction with the instructions in Deut 11 to place the blessing on Mt. Gerizim, and in Deut 27 to build an altar there. Lexical and conceptual connections between the three loci provide the basis for this reading: the mention of blessing in Exod 20:24, and the command to build an altar of unhewn stones in Exod 20:25 and Deut 27:5-6.

\begin{tabular}{|c|c|}
\hline Exodus Altar Law & Parallels in Deut 11 and 27 \\
\hline (20:24) וזבחת עליו את עלתיך ואת שלמיך & (27:6-7) והעלית עליו עולת....וזבחת שלמים \\
\hline (20:24) אבוא אליך וברכתיב & (11:29) ונתתה את הברכה על הר גרזים \\
\hline (20:25) ואם מַזבח אבנים תעשה לי & (27:5) ובנית שם ... מזבח אבנים \\
\hline 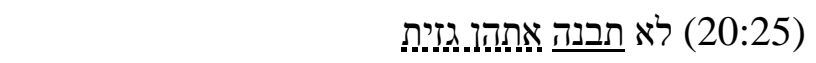 & 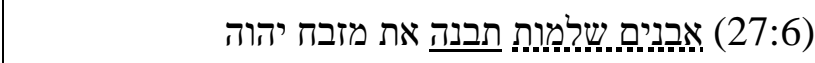 \\
\hline (20:25) כי חרבך הנפת עליה ותחללה & (27:5) לא תניף עליהם ברזל \\
\hline
\end{tabular}

${ }^{39}$ Knoppers, Jews and Samaritans, 194-212. 
These parallels allow for an interpretation according to which Exod 20:24-26 and Deut 11:29-30 + 27:4-7 must be related in some way. Such an interpretation could be bolstered and clarified by a reading of Deut 12 , which restricts sacrificial worship to a single location. ${ }^{40}$ Reading the Exodus altar law in light of both the Gerizim material in Deut 11 and 27 and the centralization command in Deut 12 quite plausibly gives rise to the idea that the altar law in Exod 20 is not about altars in general or a plurality of altars, but about the one specific altar that according to Deuteronomy should be built on Mt. Gerizim. ${ }^{41}$ This interpretation, of course, was eventually enshrined in the text of SP when Exod 20:24 was altered to read במקום, "in the place," instead of בכל המקום, "in every place.",42

If the Covenant Code's altar law was being read in this way, as a command to build an altar on Mt. Gerizim, as commanded by Moses in Deut 27, then a new dimension of the logic behind the Samaritan $10^{\text {th }}$ commandment comes into view. The hermeneutical question, from the perspective of the Samaritan reader, becomes: if the altar law in Exod 20 is about the altar on Mt. Gerizim, why is it not more explicit? Why does it not provide the same details as the command later given by Moses in Deut 27? Surely these details must also have been revealed at Sinai-or to put it another way, surely Moses's command in Deut 27 cannot deviate in any way from God's earlier command. Seen in this light, inserting the fuller, more explicit command from Deut 27 into the Sinai pericope becomes a means of explicating or providing precedent similar to what happens with Deut 5 and 18 in earlier stages of the development of SP.

${ }^{40}$ Note Deut 27:7 reinforces this connection with its reference to eating and rejoicing before YHWH; see Deut 12:18 as well as 16:11, each of which speaks of rejoicing "before YHWH" at YHWH's chosen place. For further connections between Deut 12 and 27 (suggesting that Deut 27 thus identifies YHWH's chosen place as Mt. Gerizim), see S. Schorch, "The Samaritan Version of Deuteronomy and the Origin of Deuteronomy," in Samaria, Samarians, Samaritans: Studies on Bible, History and Linguistics (ed. J. Zsengellér; Berlin: De Gruyter, 2011), 2337, at 26-29. See also Knoppers's argument that the proximity of the mention of Mt. Gerizim in Deut 11:29-30 and the centralization law of Deut 12 reinforced the impression that Mt. Gerizim was YHWH's chosen place (Jews and Samaritans, 206).

${ }^{41}$ For this line of thinking, see Knoppers, Jews and Samaritans, 208.

${ }^{42}$ Note that a technical ambiguity in the MT reading might also have facilitated the SP interpretation. MT in context must mean "in every place," as interpreted by the Septuagint and other witnesses. But grammatically speaking, כל ה ה singular noun can either refer distributively, to the entire number of that thing ("each/every X"), or refer to the entirety of some individual thing ("the whole X"). See Gesenius' Hebrew Grammar, \$127b. Thus technically בכל המקום could mean "in the whole place" (the entirety of a single place) as well as "in every place" (referring to multiple places). 
There is certainly an "ideological" or polemical valence to this addition, especially in its placement within the Decalogue, as divine speech heard by the entire nation, not just Moses. ${ }^{43}$ But recognizing the polemic should not blind us to the ways in which this too is an exegetical reading, responding to a gap or inconsistency that emerges when the text is read from a certain point of view. And it is not just any kind of exegetical reading, but one that shows very close connections with the hermeneutical perspective evidenced in the other major coordinating additions of SP and the pre-SP manuscripts. If a concern with the coordination of commands and speech events is evidenced in various Judean pentateuchal manuscripts of the late Second Temple period, it is also witnessed in the only large-scale additions in SP that are truly Samaritan.

This analysis of the Samaritan $10^{\text {th }}$ commandment further strengthens the important points made by Knoppers in his new book. Although the discovery of the pre-Samaritan Qumran manuscripts has made clear that some kind of historical connection existed between these texts and SP itself, this evidence is easily misconstrued. Scholars frequently speak of the Samaritans "adopting" or "choosing" or "acquiring" a specific form of the Pentateuch (that is, the pre-SP form known from Qumran) to serve as the basis for their ideologically Samaritan version. ${ }^{44}$ Such language creates the impression that the Pentateuch was properly "Jewish" and was not "owned" by the Samaritans until the sectarian edits were introduced. ${ }^{45}$ While no one would deny that the Pentateuch was known in Samaria, the implication is that Judea/Jerusalem was the center in which text production took place, while Samaria was part of a periphery whose elite may have engaged with or been consumers of the texts originating from the center, but did not play a role in producing them. But the common scribal techniques and hermeneutical concerns evidenced in Judean texts (including the pre-SP mss) and the "sectarian" layer of SP itself suggest a more complex picture. As Knoppers stresses, the Pentateuch must have been the "common patrimony" of Jews and Samaritans (or better: Judeans and Samarians) in the Second Temple period, and this must have extended to text production as well. ${ }^{46}$ Samarian scribes must have been engaged in transmission of the Torah for several centuries prior to a permanent souring of relations, and the

\footnotetext{
${ }^{43}$ Knoppers, Jews and Samaritans, 184.

${ }^{44}$ See e.g. Eshel and Eshel, "Dating," 238-39 (followed by Ben-Dov, "Early Texts," 228); Zahn, Rethinking, 135.

${ }^{45}$ See especially Kartveit, who suggests that the Samaritans "made it [the Pentateuch] their own and revised it..." (Origin, 259); similarly, Rofé, "Historico-Literary Aspects," 31.

${ }^{46}$ On the terminology, see Knoppers, Jews and Samaritans, 14-17.
} 
parallels in the manuscript evidence show that they must have been in close communication with their Judean counterparts. ${ }^{47}$ In other words, when the sectarian Samaritan Pentateuch was produced, Samaritan scribes based it on a text form that they not only found more amenable than other versions, but that they (or, more precisely, their Samarian predecessors) likely had played a part in producing. ${ }^{48}$

\section{Implications}

The above survey has demonstrated, first, that the changes attested in pre-SP address issues of coherence and self-referentiality in a variety of ways; and second, that a similar range of changes can be identified in manuscript contexts independent of the putative pre-SP editorial layer. Although changes concerned with indicating a command's fulfillment or the precedent for a recollection occur with unequalled frequency in the pre-SP layer, this is not the only place they occur, nor are these the only types of changes that occur in that layer. A more balanced view of the evidence suggests a rethinking of several issues pertaining to the origins and nature of SP both in its pre-SP form and in its developed "Samaritan" form.

\section{a. How did the pre-SP text develop?}

The diversity within the pre-SP layer and the attestation of the same types of changes outside of it force us to refrain from assuming that the pre-SP layer is the product of a single editorial moment. Even though all the major changes in pre-SP relate in some way to textual coherence and self-referentiality, such concerns were clearly widespread, and we know that numerous scribes introduced revisions meant to address them. It therefore seems we must allow for a range of possibilities:

- Perhaps the pre-SP layer was created by a single editor, as many have assumed.

-Perhaps all the command-fulfillment additions (i.e. in the plague narrative), or all the recollection-precedent additions, or both, were the work of a single scribe, while other types of changes, like the transpositions in the Tabernacle material or the insertion from Numbers after Deut 2:7, were introduced separately.

\footnotetext{
${ }^{47}$ Knoppers, Jews and Samaritans, 188-89; see also idem, "Parallel Torahs and Inner-Scriptural Interpretation," in The Pentateuch: International Perspectives on Current Research (ed. T. Dozeman, K. Schmid, and B. Schwartz; FAT 78; Tübingen: Mohr Siebeck, 2011), 507-31, at 525-30.

${ }^{48}$ Crawford, "Pentateuch as Found," 131.
} 
-Perhaps some of the recollection-precedent additions were added together (e.g. those pertaining to single textual units like Exod 20 or Num 20-21), while others (perhaps especially isolated examples such as Jacob's dream [Gen 30:36 SP] or the Israelites' complaint [Exod 6:9 $\mathrm{SP}])$ were added at different times.

-Perhaps, at the other extreme, these changes were introduced one by one, and gradually accumulated over a couple of centuries of copying.

To me both the first and last of these possibilities seem unlikely, the first because of the evidence presented above, and the last because it stretches the bounds of plausibility to suggest that none of the numerous functionally and formally identical changes originated together. It rather seems quite plausible that sets of changes targeting specific text units (such as the command-fulfillment additions in the plague narratives, or the expansion of the wilderness narratives in Numbers in light of Deuteronomy) would have been introduced (largely) by a single scribe. But it goes far beyond the evidence to extrapolate from such specific sets of changes to conclude that the pre-SP layer as a whole was the product of a single editorial moment. As is unfortunately often the case in dealing with Second Temple evidence, we have to keep multiple possibilities on the table.

\section{b. When did pre-SP develop?}

The possibility that the pre-SP layer did not originate all at once complicates efforts to date the emergence of this text-form. Instead of trying to date a single editorial moment (already a difficult task), we must recognize that different readings or groups of readings could have arisen at different points in time. The methodological implication is that a clear date (or, as the case may be, a clear terminus ante quem) for any given reading cannot automatically be used to date all of the others. For example, the earliest Qumran scroll classified as pre-Samaritan, 4QExod-Lev ${ }^{\mathrm{f}}$, dates to the mid-3 ${ }^{\text {rd }}$ c. B.C.E. Some have suggested that the pre-SP layer as a whole must therefore predate this manuscript. ${ }^{49}$ This suggestion is doubtful: 4QExod-Lev ${ }^{\mathrm{f}}$ is quite fragmentary and in fact preserves only one major pre-SP reading, the plus pertaining to the creation of the Urim and Thummim after Exod 39:21. ${ }^{50}$ Thus it proves only that this particular reading was extant by the mid- $3^{\text {rd }}$ c.; it tells us nothing about the rest of the pre-SP Sondergut. Indeed, since the two additions on the Urim and Thummim represent a type of concern with

${ }^{49}$ Kartveit, Origin, 299. 42.

\footnotetext{
${ }^{50}$ For a description, see Lange, Handbuch, 62. This point is also noted by Ben-Dov, "Early Texts," $221 \mathrm{n}$.
} 
coherence not frequently attested in pre-SP, it is especially unjustified to draw wider conclusions on the basis of this single plus. Even a better-preserved text like 4QpaleoExod ${ }^{\mathrm{m}}$-which indicates that nearly all the distinctive pre-SP readings in Exodus must date prior to this manuscript's production in the $1^{\text {st }}$ c. B.C.E. - cannot prove that pre-SP readings in other books also already existed. Ultimately we can only use Second Temple manuscript evidence as a guide to dating the specific readings actually attested, not the pre-SP "layer" as a whole..$^{51,52}$

\section{c. The Social Context and Background of the pre-SP Changes}

Throughout the history of the scholarly study of SP, its characteristic changes (what we have here been calling the pre-SP changes) have tended to be described as "vulgar," "popular," or (more recently) "free." 53 Ben-Dov has decisively refuted this characterization, arguing that the pre-SP changes should be seen as precisely the opposite: as highly scholarly, deeply intentional attempts to produce a more perfect version of the Torah. As a model, Ben-Dov references the work of the Alexandrian grammarians who labored to isolate the original, irreproachable text of Homer's Iliad and Odyssey. Yet Ben-Dov, referencing specifically "large-scale duplications of verbatim (or almost-verbatim) text"; that is, most of the distinctive pre-SP changes, regards these as a "comprehensive revision" representing the work of a narrow group of "pre-Samaritan critics" 54 : this was "an academic project, fully self-aware and almost entirely consistent, which is the fruit of an organized effort by trained scholars, aiming to produce a clear and coherent Pentateuch." 55

${ }^{51}$ For the paleographic date of 4QpaleoExod ${ }^{\mathrm{m}}$, see A. Lange, Handbuch der Textfunde vom Toten Meer 1 (Tübingen: Mohr Siebeck, 2009), 65, 80. Besides 4QNum ${ }^{\mathrm{b}}$ (around the turn of the era), other manuscripts attesting major pre-SP readings are: 4Q158 (50 B.C.E.-0), 4QTest (end of $2^{\text {nd }}$ c. B.C.E.; see Eshel and Eshel, "Dating," 229), 4Q364 (mid-1 ${ }^{\text {st }}$ c. B.C.E.).

${ }^{52}$ Of course the manuscript evidence is not our only source of information: in point of fact, some scholars rely on historical reconstruction (as opposed to manuscript evidence) to establish a terminus ante quem for the preSP Sondergut of around 100 B.C.E.. The reasoning is as follows: since all of the distinctive readings in the pre-SP Sondergut also appear in SP, it stands to reason that they must all have been present in the version of the Pentateuch to which Samaritan scribes made their few sectarian changes. The production of SP itself, in turn, can be dated to the late $2^{\text {nd }} /$ early $1^{\text {st }}$ centuries B.C.E., in the wake of the deterioration of relations between Judeans and Samarians under the Hasmoneans and Hyrcanus's destruction of the temple at Mt. Gerizim in 111/110 B.C.E.. For this position, see e.g. Knoppers, Jews and Samaritans, 188; Crawford, "Pentateuch as Found," 132.

${ }^{53}$ Ben-Dov, "Early Texts," 212; for earlier periods see D. A. Teeter, Scribal Laws: Exegetical Variation in the Textual Transmission of Biblical Law in the Late Second Temple Period (FAT 92; Tübingen: Mohr Siebeck, 2014), [174-79].

54 "Early Texts," 221. Note Ben-Dov takes account of the manuscript evidence that not all changes happened at the same time by describing this as an "initial wave" (220) that was later expanded upon.

55 "Early Texts," 224. 
Ben-Dov is absolutely correct to view pre-SP as a scholarly, rather than a popular, product. The evidence pertaining to pre-SP that I have presented here, however, suggests that what he depicts as an academic project restricted to a small circle of scribes is really a much broader phenomenon. If, as I have suggested, the specific concern with command-fulfillment and recollection-precedent was not restricted to a single group but finds wide currency in early Jewish texts, then it is not just a few pre-Samaritan scribes whose work should be described as academic. The evidence that not all of these changes even in the pre-SP Sondergut necessarily originated together points in the same direction. Building on Ben-Dov's insight, then, we can point to numerous instances of concern with narrative coherence and the Torah's selfreferentiality in early Jewish manuscripts, and ask how this broader body of evidence relates to Alexandrian scholarship on Homeric texts.

To be clear, Ben-Dov is careful to avoid suggesting "an outright dependence of the preSamaritan texts on Aristotle and Greek literary criticism." ${ }^{, 56}$ Instead, he implies an underlying cultural continuity whereby engagement with ancient authoritative texts produced parallel concerns about textual coherence in both Hellenistic Alexandria and Hellenistic Palestine. Nevertheless his observations join with the results of this study to raise some interesting and highly significant questions concerning the cultural and historical background of these concerns.

1. The parallel with Greek scholarship is a good one, but most properly it should be expanded to include a wider set of concerns; indeed, a much wider set than is attested in SP, even with all its diversity. "Narrative coherence" as defined by Aristotle and the Alexandrian grammarians touched on issues of plot, but also style (e.g., the frequent repetitions in Homeric epic) as well as issues we would call ideological or theological. ${ }^{57}$ If we took seriously the work of the Alexandrian grammarians as a model for what kinds of issues might fall under the purview of the academic work of Yahwistic scribes, many more types of textual interventions should be included. The goal of creating a "perfect text" (or better, recovering the perfection inherent in the text) could involve insertion of new material, grammatical or linguistic updates, harmonizations,

56 "Early Texts," 226.

${ }^{57}$ M. Niehoff, Jewish Exegesis and Homeric Scholarship in Alexandria (Cambridge: Cambridge University Press, 2011), esp. 9-12, 26-30, 38-74. 
rearrangements - really the whole host of editorial activities witnessed in Second Temple manuscripts. ${ }^{58}$

2. The connection of the pre-SP changes particularly with Greek models of literary coherence may obscure other types of precedents. Ben-Dov is not impressed by potential ancient Near Eastern parallels, noting that "the phenomenon examined here [i.e., command-fulfillments and recollection-precedents in pre-SP] is by no means typical of ancient Near Eastern literature, and finds more convincing orientation in the world of Hellenistic scholarship." 59 But studies of the Gilgamesh epic and other texts by Tigay, Tertel, and Carr show that similar concerns did exist in ancient Mesopotamia: revisions of these texts often served to harmonize and connect various passages with one another. ${ }^{60}$ Though ancient Mesopotamia provides few if any exact analogues to the specific concerns of many of the pre-SP changes, the same can be said of the Hellenistic world. One wonders whether part of the appeal of the Hellenistic parallels lies simply in the fact that Aristotle and his Alexandrian colleagues provide us with theoretical discussions of their views of what makes a proper narrative, whereas for Palestine and Mesopotamia we can only guess.

Another part of the appeal, of course, lies in the temporal and cultural proximity of the Alexandrian examples and Second Temple Jewish texts: both are products of the Hellenistic world of the late first millennium B.C.E. Yet this chronological parallel points to a key question that remains to be answered: should the scribal processes of Second Temple Judaism be regarded as fundamentally new? Or should we view them as essentially continuing theories and modes of text production witnessed in earlier periods? Some would argue that the increasing centrality and sacrality granted to the nascent Torah and other texts in the Persian and Hellenistic periods gave

${ }^{58}$ As Ben-Dov notes, the wide variety of textual features that could attract (equally varied) explanations in light of the text's presumed perfection has been demonstrated by J. Kugel, Traditions of the Bible (Cambridge: Harvard University Press, 1998), e.g. p. 17, "In similar fashion, all sorts of other, apparently insignificant details in the Bible - an unusual word or grammatical form, any repetition, the juxtaposition of one law to another or one story to another-all were read as potentially significant, a manifestation of Scripture's perfection."

59 "Early Texts," 226.

${ }^{60}$ J. H. Tigay, The Evolution of the Gilgamesh Epic (Philadelphia: University of Pennsylvania Press, 1982), 81-103; H. J. Tertel, Text and Transmission: An Empirical Model for the Literary Development of Old Testament Narratives (BZAW 221; Berlin: De Gruyter, 1994), 20-56; Carr, Formation, 40-48, 90-91. Note especially Tertel's statement (54-55) that "increasing parallelism and repetition...dominates the literary development of all epics investigated above" (i.e., Anzu, Atrahasis, Etana, and Gilgamesh). 
rise to a new focus on interpretation. ${ }^{61}$ It is hard to dispute this given the historical evidence that we have, and in this light it may make sense to attribute part of this shift to the influence of Alexandrian scholarship, along with the internal factors that Kugel stresses. On the other hand, various indicators suggest that precursors to the scribal and exegetical techniques of the late Second Temple period existed in earlier periods. These include the Ancient Near Eastern materials, of course, but also analyses of biblical materials that detect the same processes beneath the surface of the earliest extant forms of biblical texts. ${ }^{62}$ Perhaps what we perceive as the new prominence of scribal exegesis in the Second Temple period reflects less a new way of dealing with authoritative texts than a more widespread and intensive - to say nothing of better documented! - application of techniques for reading and copying texts that had been around for centuries. $^{63}$

Such broad questions return us to the difficulties inherent in attempting to extrapolate information about the cultural and social location of scribes from the textual remains that have come down to us. This consideration of the nature and origins of the scribal activities attested in pre-SP has complicated recent attempts to situate those activities; thus in a sense I have advocated a move back towards greater uncertainty regarding this material. But by showing how what appears to us as a distinctive pre-SP Sondergut is in reality enmeshed in much broader scribal trends, I hope to have illustrated how SP carries an importance far outweighing its relatively restrained revisions. When attention is paid to the full scope of their internal diversity and their parallels in other manuscripts, SP and its pre-SP forebears can serve as a critically important lens for exploring those difficult questions concerning Second Temple Jewish scribal practice.

${ }^{61}$ See Kugel, Traditions, 4-14; in more detail, idem, "Early Interpretation: The Common Background of Late Forms of Biblical Exegesis," in Early Biblical Interpretation (by J. Kugel and R. Greer; Philadelphia: Westminster, 1986), 11-106, esp. 27-39.

${ }^{62}$ The entire body of scholarship concerned with "Inner-Biblical Exegesis" provides potentially relevant examples. A wonderful entry point into this literature is the bibliographic essay by B. M. Levinson, Legal Revision and Religious Renewal in Ancient Israel (Cambridge: Cambridge University Press, 2008), 95-181.

${ }_{63}$ Tigay and Carr both note that, in the ancient Near East, prestigious texts tend to be increasingly subject to harmonizing/coordinating scribal activity in later versions (Tigay, Gilgamesh, 100-101; Carr, Formation, 90-91). Thus, the increasing efforts at harmonization seen in Second Temple texts are in a way precisely what we might expect as certain texts gained in centrality and prestige (a process that could have been influenced both by the increasing age of these texts and by sociohistorical factors like an increased focus on written traditions). On the continuities between the scribal activities detected in biblical books via literary criticism and those attested in Second Temple texts and manuscripts, see also R. Kratz and M. Popović, "Editorial Note," DSD 20 (2013): 347-48; A. Teeter, "The Hebrew Bible and/as Second Temple Literature: Methodological Reflections," DSD 20 (2013): 349-77. 